\title{
Innovation Strategies for Improving the Quality of Students' Educational Research Project in the Ph.D. Programme of Ebonyi State University, Abakaliki
}

\author{
Paul Nwakpa \\ Department Of Educational Foundations \\ Faculty Of Education, Ebonyi State University, Abakaliki, Nigeria \\ Email: bropaulnwaoo [AT] gmail.com
}

\begin{abstract}
This study investigated innovative strategies for improving the quality of students' research projects in the Ph.D programme of Ebonyi State University, Abakaliki, Nigeria. To achieve this purpose, two research questions and one null hypothesis guided the study. The population for the study consisted of twenty (20) professors and one hundred and thirty (130) senior lecturers, totaling one hundred and fifty (150) respondents who teach Ph.D students all of the faculty of education, Ebonyi State University. The sampling technique adopted for this study was the total census technique due to the smallness and manageability of the population. Questionnaire titled "Innovative Strategies for Improving Students' Research Dissertation Questionnaire” (ISISRDQ) was used to collect data from the respondents. The instrument was validated by three experts in measurement and evaluation of the department of science education of Ebonyi state University. Re-reliability of the instrument was tested using cronbach Alpha statistic and it yielded an index of 0.84 which was adjudged high enough for measuring the consistency of the items. The method of data collection was done by the researcher alone by going to the individual respondent's office for distributing and collecting the copies of the questionnaire, and this exercise lasted for two weeks. The method of data analysis includes mean, standard deviation and test. The results of the study revealed some innovative strategies to be adopted and used to improve students' research projects. Based on the findings, it was recommended that lecturers in the Universities should ensure that students' research projects are organized in accordance with the suggested innovative strategies.
\end{abstract}

Keywords---- Innovation, Strategies, Improving, Quality, Students, Educational, Research, Project

\section{INTRODUCTION}

Writing is essentially very difficult to learn. However, there are established strategies, standards and rules for writing which are usually not easy to come by. This is much so with dissertation writing which entails writing on demand rather than "Bread and butter writing". Research is the master key to the development of any nation. Experience has shown that most students that have taken courses in research methods and educational statistics are benefit of the necessary skills and techniques for the production of high quality "final" manuscript. They tended to muddle through in the project, thesis or dissertation writing. Generally, writers are prone to errors and limitations.

Research has become the most reliable means available to man to acquire knowledge. it is an exercise that combines intellectual skills with mechanical activities. Research writing calls for proper mastering of new, useful and vital research skills and techniques that are defined necessary for careful collection and analysis of special forms of information under defined strategies, conditions and procedures. (Child)5 stated that project writings a systematic, organized and controlled process involving observations and the analysis of such observations aimed at discovering the truth. It involves the use of materials and tools by students under the supervision of lecturers. The purpose of the project according to (Sule)14 is to develop and test students' skills on basis of the normal range covered by the critical lessons along. In addition, practical projects improve students' knowledge of tools and materials as well as assist them develop positive attitudes towards work (Garba)7.

Dissertation project accounts for six credit units in the Ph.D Education programme and forms part of the total compulsory minimum credit loads required for graduation. A Ph.D programme takes a minimum of three academic year in the ratio of one academic year for course work and two academic years for the research work (Thesis writing). (Garba)7 asserted that students' research work is a scientific undertaking aimed at the understanding of objects and event in the world. Been a scientific activity, it has the characteristics of science, which are, of course, shared with non-science activities these include such activities as:

a. Description

b. Discovery of the regularity of events or objects and 
c. The generation of theories and laws.

Therefore, for the achievement of educational objectives, the student should be trained in the general technical skills and attitudes. (Audu) 2 stated that internal supervision in the context of practical research projects is to provide useful hints, counsel and advice for the neophytes who are interested in delving into the unknown mysteries of writing well. He expressed concern for precision, accuracy, rightness of tones, modesty, effectiveness in communication, and highlighting pertinent mechanical aids, what is false, what amounts to evasion and fraud. Therefore, the concept of students practical project supervision can be seen as a process or an activity by which an individual or group of individuals offer guidance services by means of advising, overseeing, controlling, stimulating, evaluating and improving students work to achieve the objectives of the programme. Supervisors of students' research dissertation have two responsibilities to perform in the areas of guidance and evaluation. The guidance aspect has to do with helping students to make maximum use of their talents in carrying out practical projects. (Ipaye) 10 stated that guidance is an organized effort aimed at assisting the individual student to develop his capability to the highest level. The guidance aspect in the supervision projects is an orderly approach aimed at assisting students towards the determination of their talents. Supervisors' evaluation role concerns obtaining evidence about the progress of students in the Ph.D. programme through a systematic procedure. These include keeping records of students' performance; using appropriate techniques obtain evidence and analyzing the data acquired for the purpose of decision making. Unfortunately, available research studies revealed that the ways students are supervised do not assist them acquire relevant skills in planning, developing and constructing functional practical project. (Audu and Bukar)2 noted that the strategies employed by lecturers in supervising students practical projects give room for the student not to concentrate and produce quality and functional projects. There is also the problem associated with procedures employed by the lecturers in evaluating projects. The use of improper evaluation methods, not being conversant with the project topic and evaluation procedures as well as tight schedule of supervisors are some of the obstacles to the production of quality project (Ikeoji)9. It is against this background, therefore, that the problem of this study could be asked in the question: what are the innovative strategies for improving the quality of students' educational research projects in the Ph.D programme at Ebonyi state university, Abakaliki?

\section{PURPOSE OF THE STUDY}

The major purpose of this study was to determine the innovative strategies for improving the quality of students' educational research projects in Ph.D programme of Ebonyi State University, Abakaliki.

Specifically, the study:

1. Determined the innovative guidance strategies for improving the students' research projects in the Ph.D educational programme.

2. Ascertained the innovative evaluation strategies for improving students' research projects in the Ph.D educational programme.

\section{RESEARCH QUESTIONS}

The following two research questions were formulated and guided the study:

1. What are the innovative guidance strategies for improving students' research projects in the Ph.D educational programme?

2. What are the innovative evaluative strategies for improving students' research projects in the Ph.D educational programme?

\section{HYPOTHESIS}

Ho$_{1}$ : There is no significant difference in the mean responses of senior lecturers and professors on the innovative strategies for improving students' research projects in the Ph.D educational programme.

\section{METHODOLOGY}

The study adopted descriptive research design which involved collecting data in order to test hypothesis and answer research questions raised in the study. The population for the study comprised of one hundred and twenty (120) lecturers from the rank of senior lecturers and professors in the faculty of education. Since the population of the study was small, the census survey involving the 120 respondents was used to avoid sampling errors and control maturation. The study sought information from the six departmental lecturers who teach Ph.D students.

A structured questionnaire titled, "Innovative Strategies for Improving Students' Research Dissertation Questionnaire" (ISISRDQ). The face-validity of the instrument was determined at the construction stage by given it to three experts in measurement and evaluation in the Department of Science Education, Faculty of Education, Abia State 
University, Uturu, Abia State. The experts scrutinized the research questions and questionnaire items carefully and necessary observations that led to some correction and the final draft of the questionnaire. The reliability of the instrument was tested using Cronbach Alpha statistics and it yielded an index of 0.84 . Out of 120 copies of questionnaire filled by the respondents, 120 were collected and used. Mean, standard deviation and t-test were employed for data analysis. Mean and standard deviation were used in answering the research questions, while t-test statistic was employed for testing the hypotheses at 0.05 level of significance.

\section{RESULTS}

\begin{tabular}{|c|c|c|c|c|c|c|}
\hline $\mathbf{S} / \mathbf{N}$ & $\begin{array}{l}\text { GUIDANCE STRATEGIES FOR IMPROVING } \\
\text { RESEARCH PROJECTS }\end{array}$ & $\begin{array}{l}\text { SENIOR } \\
\text { LECTURE } \\
\mathrm{R} \\
\mathbf{S} N=105 \\
\overline{\mathbf{X}} 1\end{array}$ & $\begin{array}{l}\text { PROFESSORS } \\
\mathbf{N}=15 \\
\overline{\mathbf{X}} 2\end{array}$ & $\mathbf{X}$ & SD & DECISION \\
\hline 1 & $\begin{array}{l}\text { Guard students to employ the approved style } \\
\text { recommended by the supervisors, the department or } \\
\text { the institution. }\end{array}$ & 4.47 & 4.30 & 4.40 & 0.54 & Agree \\
\hline 2 & $\begin{array}{l}\text { Guard students to place accurate citations and } \\
\text { referencing }\end{array}$ & 4.31 & 4.02 & 3.93 & 0.80 & Agree \\
\hline 3 & $\begin{array}{l}\text { Guard students to identify statements that are not } \\
\text { supported by concrete evidence. }\end{array}$ & 4.08 & 3.89 & 4.31 & 0.76 & Agree \\
\hline 4 & $\begin{array}{l}\text { Ensure that students select right tools and materials } \\
\text { for the project. }\end{array}$ & 4.14 & 4.22 & 4.29 & 0.80 & \\
\hline 5 & $\begin{array}{l}\text { Guard the researcher to avoid all elements that may } \\
\text { cause distractions such as weak and clumsy language, } \\
\text { poor grammar and being constructive in criticize. }\end{array}$ & 4.48 & 4.40 & 4.42 & 0.87 & Agree \\
\hline 6 & $\begin{array}{l}\text { Guard students to avoid very lengthy sentences and } \\
\text { biases (sexual, ethical religious etc) }\end{array}$ & 4.17 & 3.99 & 4.01 & 0.82 & Agree \\
\hline 7 & $\begin{array}{l}\text { Ensure the language is lucid, lively and to inform the } \\
\text { reader. }\end{array}$ & 4.38 & 4.46 & 4.47 & 0.08 & Agree \\
\hline 8 & $\begin{array}{l}\text { Guard students to avoid the use of technical jargons, } \\
\text { unnecessary generalizations. }\end{array}$ & 4.18 & 4.30 & 4.23 & 0.92 & Agree \\
\hline 9 & $\begin{array}{l}\text { Helping students to search from various sources to get } \\
\text { relevant information. }\end{array}$ & 3.09 & 3.37 & 3.43 & 0.69 & Disagree \\
\hline 10 & $\begin{array}{l}\text { Interact with students to discover their talents and } \\
\text { capabilities }\end{array}$ & 4.08 & 3.78 & 4.40 & 0.81 & Agree \\
\hline 11 & $\begin{array}{l}\text { Help students to avoid profuse quotations, pompous } \\
\text { and pedantic presentation, and use of colloquial style. }\end{array}$ & 4.32 & 4.78 & 4.55 & 0.55 & Agree \\
\hline 12 & $\begin{array}{l}\text { Guard students to use the active rather than the } \\
\text { passive voice }\end{array}$ & 3.07 & 3.35 & 3.42 & 0.69 & Agree \\
\hline 13 & Guard students to select tenses or nouns carefully. & 4.61 & 4.75 & 0.77 & 0.73 & \\
\hline 14 & $\begin{array}{l}\text { Ensure that students obey the rule of 'concord' } \\
\text { agreement of subject and verb }\end{array}$ & 4.08 & 3.88 & 3.96 & 0.68 & Agree \\
\hline 15 & $\begin{array}{l}\text { Guard students to know that research plans or } \\
\text { proposals are usually written in the present tense but } \\
\text { research report are always written in the past tense. }\end{array}$ & 4.10 & 3.85 & 4.24 & 0.94 & Agree \\
\hline 16 & $\begin{array}{l}\text { Counseling students to make adequate project plans so } \\
\text { as to prevent waste of time and resources }\end{array}$ & 4.19 & 4.39 & 3.88 & 0.68 & Agree \\
\hline 17 & 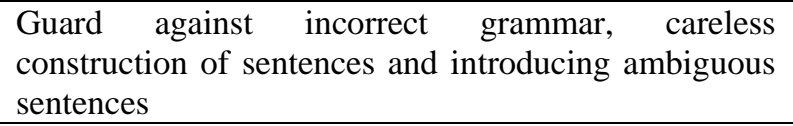 & 4.60 & 4.54 & 4.54 & 0.76 & Agree \\
\hline
\end{tabular}

$\overline{\mathrm{X}} 2=\quad$ Mean for professors

$\overline{\mathrm{X}}=\quad$ Grand mean

$\mathrm{SD}=\quad$ Standard Deviation 
Table 1 reveals that all items except item 9 have the cut off point 3.45. Respondents therefore agree that these items with the mean above the cut-off point are guidance strategies for improving supervision of student's research projects in the Ph.D (Education) programme, Ebonyi State University, Abakaliki. Item 7, 11 and 17 have the highest mean scores of 4.47 , and 4.54 respectively.

TABLE 2: Mean rating of senior lecturers' and professors view on evaluating strategies.

\begin{tabular}{|c|c|c|c|c|c|c|}
\hline $\mathbf{S} / \mathbf{N}$ & $\begin{array}{lcc}\text { GUIDANCE } & \text { STRATEGIES } & \text { FOR } \\
\text { IMPROVING RESEARCH PROJECTS } & \end{array}$ & $\begin{array}{l}\text { SENIOR } \\
\text { LECTURE } \\
\text { R } \\
\text { SN }=105 \\
\text { X1 }\end{array}$ & $\begin{array}{l}\text { PROFESSORS } \\
\mathrm{N}=15 \\
\mathrm{X} 2\end{array}$ & $\mathbf{X}$ & SD & $\begin{array}{l}\text { REMAR } \\
\text { K }\end{array}$ \\
\hline 18. & Suggest research topics for students to pick & 3.00 & 3.28 & 3.40 & 0.55 & Agree \\
\hline 19. & $\begin{array}{l}\text { Ensure that the research plans are realistic to avoid } \\
\text { waste of resources }\end{array}$ & 4.67 & 4.55 & 4.62 & 0.55 & Agree \\
\hline 20 & $\begin{array}{l}\text { Ensure that students employ the approved style } \\
\text { recommended by the }\end{array}$ & 4.62 & 4.67 & 4.66 & 0.75 & Agree \\
\hline 21 & $\begin{array}{l}\text { Ensure that students researchers are evaluated at } \\
\text { every stage }\end{array}$ & 4.46 & 4.61 & 4.58 & 0.50 & Agree \\
\hline 22 & Involve professors in the evaluation process & 3.68 & 3.87 & 3.98 & 0.78 & Agree \\
\hline 23 & Make sure that the research work is effective & 4.66 & 4.20 & 4.60 & 0.56 & Agree \\
\hline 24 & $\begin{array}{l}\text { Adopt only process evaluation to students' } \\
\text { research project. }\end{array}$ & 3.03 & 3.14 & 3.09 & 1.18 & Disagree \\
\hline 25 & $\begin{array}{l}\text { Ensure that the researcher progress beyond the } \\
\text { minimum competency }\end{array}$ & 4.46 & 4.55 & 4.50 & 0.51 & Agree \\
\hline 26 & $\begin{array}{l}\text { Incorporate macro project defense as a strategy for } \\
\text { evaluation }\end{array}$ & 4.63 & 4.20 & 4.65 & 0.75 & Agree \\
\hline 27 & $\begin{array}{l}\text { Record the research difficulties encountered by the } \\
\text { student }\end{array}$ & 4.58 & 4.67 & 4.62 & 0.57 & Agree \\
\hline 28 & $\begin{array}{l}\text { Maintain accurate records of students performance } \\
\text { at all points of practical project construction }\end{array}$ & 4.13 & 4.26 & 4.17 & 0.94 & Agree \\
\hline 29 & Apply only evaluation to students research project & 3.12 & 3.18 & 3.12 & 1.19 & Disagree \\
\hline 30 & $\begin{array}{l}\text { Employ process and product evaluation of } \\
\text { students' research project. }\end{array}$ & 4.47 & 4,72 & 4.59 & 0.57 & Agree \\
\hline 31 & $\begin{array}{l}\text { Make use of checklist and rating as a guide in the } \\
\text { evaluation process of students' research project }\end{array}$ & 4.14 & 421 & 4.16 & 0.93 & Agree \\
\hline 32 & $\begin{array}{l}\text { Provide feedback to students of their performances } \\
\text { at all stages of evaluation }\end{array}$ & 3.82 & 3.98 & 3.85 & 0.88 & Agree \\
\hline
\end{tabular}

$\overline{\mathrm{X}} 1=$ mean for senior lectures,

$\bar{X} 2=$ mean for professors

$\bar{X}=$ Grand mean

$\mathrm{SD}=$ standard Deviation

Table 2 shows that except items 18,24 and 29 with 3.40, 3.09 and 3.12 all other items have their mean scores higher than cut off point of 3.45. This implies that respondents agree with these items whose means are grater than the cut off point as evaluation strategies for improving the quality of students projects. 


\section{Hypothesis I}

There is no significant difference in the mean responses of senior lecturers and professors on the improvement strategies for students research dissertations in the Ph.D Education programme.

Table 3: T-test summary of senior lecturers and professors on the improvement strategies for students research dissertations.

\begin{tabular}{|l|l|l|l|l|l|l|l|}
\hline Respondents & $\mathbf{n}$ & $\mathbf{x}$ & Sd & DF & t-Cal & t-crit & Decision \\
\hline Professors & 15 & 2.75 & 1.08 & & 1.73 & $\mathbf{1 . 9 6}$ & Not significant \\
\hline Senior Lecturers & 105 & 2.53 & 0.69 & 64 & & & \\
\hline
\end{tabular}

The result in table 3 shows that the calculated t-value of 1.73 is less than the t-critical value of 1.96 at 0.05 level of significance. In other words, the null hypothesis HO, is accepted. There is no significant difference between the mean response of senior lecturers and professors on the improvement strategies for students' research dissertations.

\section{FINDINGS}

The major findings of this study are:

a. Guiding the students to employ the approved style recommended by the institution.

b. Counseling the students to make adequate plans for conducting research projects so as to minimize waste of time and resources.

c. Guiding the students to avoid the use of technical jargons and unnecessary generalization

d. Research topics should not be suggested for the students to pick.

e. Interacting with students to discover their talents, capabilities and areas of difficulty.

f. Ensuring that students research work are evaluated at every stage.

g. Employ process and product evaluation to students research projects.

h. Providing feedback to students of their performance at all stages of evaluation.

Result of the Hypothesis testing in the study indicated that there is no significant difference in the mean response of senior lecturers who teach Ph.D students and professors on improvement strategies for supervision of students' dissertation project in $\mathrm{PhD}$ education programme, Ebonyi State University, Abakaliki.

\section{DISCUSSION}

The result of this investigation showed that professors are involved in the supervision and evaluation process. They guard the students to avoid very lengthy sentences, technical jargons and unnecessary generalization. The finding revealed that the lecturers and the professors counsel the students to make plans for conducting practical research projects so as to minimize waste of time and resources and that research topics should not be suggested for the students to pick. These findings are in agreement with (Harrison)8, dissertation that teaching and learning s such as practical projects could be enhanced through guidance. Guiding students to place accurate citations and referencing will offer opportunities for students to improve their competencies towards the attainment of the aims and objectives of thesis writing. Surely, the goal of supervision for arousing the creative and productive talents of students could be attained (Sule)14 and (Kyle) 11 added that guidance strategies will enable students to be courageous in their abilities. Peters and Farewell in (Ipayel)10 also affirmed that through guidance techniques, students would be assisted to make plans and preparation for the purpose of accomplishing any educational tasks such as selection of proper tools/materials for practical projects. The study by (Harris and Smith)8 reveals that quite a number of students dislike the idea of supervisions recommending project topic. One of such students boldly pointed out that this makes him completely lose interest in the project work.

Findings of the study on evaluation strategies for improving students' research projects include adoption of process and product evaluation on students' project; providing feedback to students of their performances at all stages in the course of carrying out the project; maintaining accurate records of students' performances and involving professors in the evaluation process. All these finding are also supported by assertions of many authors. (Okoro) 13 observed that a more accurate evaluation of practical projects is made by combining process and product evaluation. Whereas process evaluation is conducted spasmodically while project work is being undertaken, product evaluation on the other hand is 
carried out on the completed students' projects. Therefore, application of both methods would be an improvement strategy for supervision of students' practical projects. It also means clarification of areas of students' shortcomings and the determination of the degree to which the students acquired the expected practical skills (Ogwo and Oranu) 12 . Providing feedback to students of their performance is also in conformity with the views of (Child) 5 who ascertains that this is the base upon which motivation principles are established. Students' enthusiasms are therefore augmented whenever feedback is used as an evaluation strategy. Maintenance of accurate records of students' performances is in agreement with the views of (Garb)7. He indicated that the evaluation role of the supervisor is that of obtaining evidence about students' progress and performances. This carried out through a systematic procedure. (Dynan and Kepa)6 and (Allison and Benson) 1 also justified the findings of the study on involvement of professors in the evaluation process. Uniformity of students' scores in practical projects could be attained by involving professors as second assessors. The non-significance in the mean response of senior lecturers who teach the $\mathrm{PhD}$ students and professors might be on the ground that use the same improper technique.

\section{RECOMMENDATIONS}

The following recommendations were made based on the finding of the study.

1. Supervisors of research projects should interact properly with the students. This is for the purpose of helping the students to discover their talents and potentialities.

2. The department should design a format which would be used in all areas of specialization for process and product evaluation of students' research projects.

3. Students should be allowed to pick their project topics. This would offer an opportunity for the students to justify their work.

\section{CONCLUSION}

The purpose of this study was to determine the improvement strategies for students' research projects in the Ph.D (Education) programme of the Ebonyi State University Abakaliki. The study has revealed that research projects could be enhanced through effective guidance and evaluation of students' work. The guidance element includes interaction with the students to discover their talents and capabilities in carrying out the projects, counseling them to make adequate plans so as to minimize waste of time and resources as well as permitting the students to choose project topics by themselves. The evaluation components of the supervision comprises the use of process and product evaluation techniques to students' practical projects; providing feedback to students of their performances at every stage of the project and finally maintaining accurate records of students' performances at all stages of the project construction. These would no doubt go a long way in facilitating the attainment of the objectives of practical projects for the Ph.D (Education) programme.

\section{REFERENCES}

1.Allison, J \& Benson, FA. (2003), Undergraduate project and their assessment. In proceedings 130r 8, $402-419$.

2.Audu, S.Q.S: Bukar B, (2000). Research supervision and students' research projects in polytechnics in Nigerian. Journal of the National Science and technology forum, 1, 1, 40 -45.

3.Bukar, B, (2004). Development of 'an instrument for evaluating practical projects in electronics. Unpublished masters' dissertation submitted to University of Nigeria, Nsukka.

4.Bukar, B. (2000). Performance evaluation and students' research projects in technical education. Journal of the National Science 3nd Technology Forum 1, 7,46-50.

5.Child, D. (2007). Psychology and the teacher. London: Holt, Rinehart and Winston.

6.Dynan, M.B.C and Kempa,. R.F, (2007). Teacher based assessment of practical work in sixth forum physics. Physics education 12, 6, $364-369$.

7.Garba, L.N. (2005). Evaluating students' practical projects in Technology education. Spectrum Journal of Kaduna polytechnic 2,132,10-12.

8.Harris, D, \& Smith, B, (2003). Undergraduate project work. Assessment and evaluation in Higher Education 8,3,246261.

9.Ikeoji, E,N. (2001). Towards an effective psychomotor evaluation in vocational education in secondary schools Nigerian vocational Journal wi, 230-239

10.Ipaye, T, (2006). Educational and vocational guidance: concepts and approach in T, Ipaye (Ed) Educational; Guidance. Ife: University of Ife press Ltd. 
11.Kyle, G.C (2000), How to supervise. New York: Haughton Miffin \& Co,

12.Ogwo, O.A \& Oranu R.N. (2006) Methodology in formal and non formal technical vocational education. Nsukka: University of Nigeria press Ltd.

13.Okoro, O.M (2003), principles and methods in vocational and technical education, Nsukka: University of Nigeria Trust publishers,

14.Sule, H.O. (2005), strategies for improving the supervision of instruction by principals of secondary schools in Kaduna state. Zana Journal of Educational Studies 7,172,2430,

15.Uzoagulu, A.E. (2004). Assessment of the practical measure for quality evaluation technical projects. Studies in. Technical Teacher Education 1, 1,150-158. 